\title{
Ant litter fauna of forest, forest edges and adjacent grassland in the Atlantic rain forest region of Bahia, Brazil
}

\author{
J.D. Majer ${ }^{1}$ J.H. C. Delabie ${ }^{2}$ and N.L. McKenzie ${ }^{3}$ \\ ${ }^{1}$ School of Environmental Biology, Curtin University of Technology, P. O. Box U 1987, Perth, \\ WA 6001, Australia, e-mail: imajerj@info.curtin.edu.au \\ 2 Centro de Pesquisas do Cacau (CEPEC-CEPLAC), 45.600.000, Itabuna, Bahia and \\ Departamento de Ciênces Agrárias e Ambientais, Universidade Estadual de Sante Cruz, \\ Ilhéus, Bahia, Brazil, e-mail: delabie@nuxnet.com.br \\ 3 Department of Conservation and Land Management, P. O. Box 51, Wanneroo, WA 6065, \\ Australia,e-mail:normm@wood.calm.gov.au
}

Key words: Rain forest, edge effect, ants.

\section{Summary}

The litter ant fauna was sampled by Winkler sacks and pitfall traps along transects running through Atlantic rain forest into an adjacent grassland. Transects ran $65 \mathrm{~m}$ into the forest and $45 \mathrm{~m}$ into the field. Ninety-seven species of ants were sampled and scored, 85 were found in the forest, 48 were found in the field and 36 were common to both habitats. There was some evidence that species richness was lowest in the field and high at the deepest point within the forest. The composition of the ant community at the different distances into the forest and field was analysed by a number of hierarchical clustering procedures and also by ordinating the data in three-dimensional space. A two-way table of the ant assemblages derived from the clustering procedure versus the groupings of transect distances obtained by the same procedure indicated that certain ant species had preferences for the field or particular distances into the forest. It is concluded that although the ant fauna of Atlantic rain forest is severely affected by clearing, a forest-like ant fauna is able to persist right up to the interior edge of the forest.

\section{Introduction}

The major reason for the decline in biodiversity around the world is loss of native habitat, principally as a result of agricultural activities. A compounding effect of this loss is the fragmentation of that habitat which remains. A number of writers have considered the consequences of landscape fragmentation in the biogeographical context of habitat and species loss (e.g., Wilcox and Murphy, 1985). In addition to this, Saunders et al. (1991) have indicated that fragmentation can interrupt ecosystem processes and that these changes can lead to further habitat decline and species loss. 
Atlantic rain forest has not escaped the problems of fragmentation. It once occupied about one million square kilometres of the eastern part of Brazil, extending from Rio Grande do Norte to Rio Grande do Sul in a strip ranging from several to $160 \mathrm{~km}$ wide. Much of it has been cleared as a result of several waves of exploitation, so much so that its loss is considered to be more severe than of any other forest types in South America (Mori et al., 1983). At the national level, less than $8.8 \%$ of this ecosystem remains (Cãmara, 1991), and much of it that still exists is represented in small fragments and linear strips of vegetation (Fonseca, 1985). Although a few sizeable nature reserves do exist, they provide an inadequate representation of the diversity of this ecosystem (Cãmara, 1991). This means that the remaining fragments of forest within the matrix of agricultural land are often the only means for conserving representatives of the original biota (Saunders et al., 1987).

Unfortunately such areas are prone to edge effects, such as changes in microclimate (Carmago and Kapos, 1995), vegetation structure and diversity (Lovejoy et al., 1986), and weed invasion, all of which can influence the vertebrate and invertebrate fauna (Malcolm, 1988; Rylands and Keuroghlian, 1988; Scougall et al., 1993; Mills, 1995; Turner, 1996). The degree to which these effects penetrate the fragment can vary and is not generally known. However, if the fragment is small and the edge effect large, its conservation potential can be severely lessened (Turner, 1996).

A reasonable number of studies have been performed on the impact of rain forest fragmentation on vertebrate animals (see review by Turner, 1996), although invertebrates have been relatively neglected. Invertebrate groups which have been studied include euglossine bees (Powell and Powell, 1987; Becker et al., 1991), termites (Fonseca de Souza and Brown, 1995), dung and carrion beetles (Klein, 1989) and butterflies (Daily and Ehrlich, 1995). Ant community structure is known to be influenced by forest clearing (Vasconcelos et al., in press) and subsequent regrowth (Vasconcelos and Cherrett, 1995), so it follows that it is also likely to be influenced by changes at the edges of forest fragments. This paper investigates the impact of edges on ant communities in Atlantic rain forest in southeastern Bahia, Brazil.

\section{Methods}

\section{Ant sampling}

Field work was carried out in April and May 1996 in the grounds of the Centre for Cocoa Research (CEPLAC), Itabuna, Bahia $\left(14^{\circ} 45^{\prime} \mathrm{S}, 39^{\circ} 13^{\prime} \mathrm{W}\right)$. The grounds are predominantly planted to cocoa, although some areas are maintained as grassland. A rectangular shaped botanical reserve of secondary rain forest, measuring about $400 \mathrm{~m} \times 1000 \mathrm{~m}$ (see map in Alvim and Rosário, 1972), exists within the grounds and is surrounded by cocoa on the northern, western and eastern sides, while the southern side adjoins a grassland which is separated by an avenue of planted shade trees along the outer margin of the forest. This is the same reserve in which Leston (1978) first described the Neotropical ant mosaic.

Starting $100 \mathrm{~m}$ from the south-west corner of the reserve, ten $110 \mathrm{~m}$ long southnorth transects were established at $50 \mathrm{~m}$ intervals along the southern edge of the reserve. The transects were staked at $10 \mathrm{~m}$ intervals and were sited so that seven 
points extended into the reserve, one occurred in the middle of the planted edge $5 \mathrm{~m}$ outside of the forest, and two were in the field; the two field stakes were situated $20 \mathrm{~m}$ and $40 \mathrm{~m}$ from the planted edge stake since it was anticipated that change in the ant community would not be at such a fine scale in the field. Litter ants were sampled by two complementary methods. All samples were taken $2 \mathrm{~m}$ to the side of the transect to avoid the effects of human disturbance caused by transect establishment. One metre square quadrats of litter were taken between $08: 30 \mathrm{~h}-11: 00 \mathrm{~h}$ and sieved to concentrate fine organic fragments and associated animals. These were placed in Winkler sacks (see Besuchet et al., 1987; Olson, 1991) and hung in a room at about $28^{\circ} \mathrm{C}$ for $24 \mathrm{~h}$ to extract ants and other invertebrates. This is not sufficient time to extract all invertebrate material but is nevertheless considered to provide an adequate qualitative sample of the presence and absence of ant species. A $75 \mathrm{~mm}$ internal diameter pitfall trap, containing water plus a drop of detergent, was established $2 \mathrm{~m}$ to the opposite side of the stake and left for $48 \mathrm{~h}$. All ant material from the Winkler sacks and pitfall traps was sorted to morphospecies level, identified to genus and, when possible, to species using the reference collection in the Myrmecology Laboratory at CEPLAC. A full reference collection for this material is deposited there.

Weather conditions were frequently overcast during much of the sampling period, intermittent rain fell during this time and daily maximum and minimum temperatures averaged respectively $28.9^{\circ} \mathrm{C}$ and $20.2^{\circ} \mathrm{C}$. Shrub/grass cover was always $100 \%$ at the three sampling points outside of the forest boundary as a result of the dense growth of grasses and shrubs. Despite the fact that cows were present in the field, the foliage was at least $60 \mathrm{~cm}$ high. Within the forest boundary, shrub/grass cover dropped to an average of $23-44 \%$, depending on the position along the transect. There was no trend in shrub/grass density along that part of the transect within the forest, although variability was increased by dense shrub cover in gaps associated with tree falls. Mean tree canopy cover varied between $80-88 \%$ along the forest part of the transect and there was no trend with distance from the field. Outside the forest margin, cover dropped from $35 \%$ along the planted edge to virtually zero at the most distant point. Cover was still over $20 \%$ at $25 \mathrm{~m}$ into the field due to the presence of scattered forest trees. Both here and along the planted edge, the variability of tree cover was high due to patchy distribution of trees. Mean litter depth ranged from 1.2-1.6 cm along the forest part of the transect and showed no trend with distance from the forest edge. Litter loads were consistently low at the two field points on the transect and, unlike within the forest, litter consisted almost solely of decaying grass material.

\section{Data analysis}

For each of the two sampling methods, matrices of the number of ants of each species per sample point were compiled. These matrices were reduced to presence/ absence data and the matrix-pairs were combined in order to give a more complete picture of the trends in ant species occurrence. The resulting matrix was then condensed by calculating the frequency (out of 10) of each ant species at the 10 points along the transects. 
The analysis package PATN (Belbin, 1995) was used to seek patterns of species composition in the data matrix. An outline of the reasoning for selecting the following procedures for detecting differences in community composition may be found in McKenzie et al. (1991). The association measure "two step" (Belbin, 1980) was used to determine the quantitative relationships between each pair of species based on their co-occurrences at sites. Secondly, the Bray-Curtis measure (see Faith et al., 1987) was used to compare the points along the transect according to similarities in their species composition. Dissimilarity values greater than 0.88 were re-estimated using the shortest path algorithm of PATN to minimize the asymptotic distortion introduced by the Bray-Curtis measure.

For both measures of association, a modified version of the "pair group arithmetic averaging", or UPGMA (Sneath and Sokal, 1973; Belbin, 1995), hierarchical clustering strategy was used. The clustering parameter (Beta) was set at -0.1 (see Belbin, 1995). There is no generally accepted method for determining the optimum number of groups that should be distinguished from a dendrogram. Consequently we cut the dendrograms horizontally at clearly visible gaps. A "two-way table" was also produced in which the 10 transect points and the 97 species of the data matrix were re-arranged according to the species and the transect point classifications.

In order to investigate the site clustering in more detail and also to confirm the robustness of the clusters, the same data were ordinated in a three-dimensional space using semi-strong hybrid scaling (Belbin, 1991). A minimum-spanning tree was then superimposed upon the resulting ordination diagram to indicate those sites which were most similar in terms of ant species composition.

\section{Results}

Ninety-seven species of ants were sampled and scored as present or absent at each sampling point. Of these species, 85 were found in the forest, 48 were found in the field and 36 were common to both habitats.

Figures $1 \mathrm{a}-\mathrm{c}$ illustrate the variation in the mean number of ant species collected by pitfall traps, Winkler sacks, and by both methods, along the transects. The mean number caught by pitfall traps ranged from 1.8-3.4 and there was little apparent trend in numbers along the transects, although the maximum richness was encountered at the furthest point into the forest (Fig. 1a). The mean number of species extracted by the Winkler sacks ranged from 3.8-7.3. It is noteworthy that the highest richness was once again reached at the furthest point into the forest and the lowest richness was encountered at the point $25 \mathrm{~m}$ into the field (Fig. $1 \mathrm{~b}$ ). The mean number of species obtained by both methods combined ranged from 6.0-9.2 species and the transect trends mirrored those of the individual sampling methods; the highest richness values were encountered at the 35,55 and $65 \mathrm{~m}$ points from the forest edge (Fig. 1c).

The dendrogram of transect positions divided the transect points into two distinct groups at the 0.64 coefficient of dissimilarity level (Fig. 2). The field and planted edge points formed one group while the other was formed by the forest points. No trends related to position along the transect were evident within either group. Five assemblages of species were produced by the corresponding dendro- 

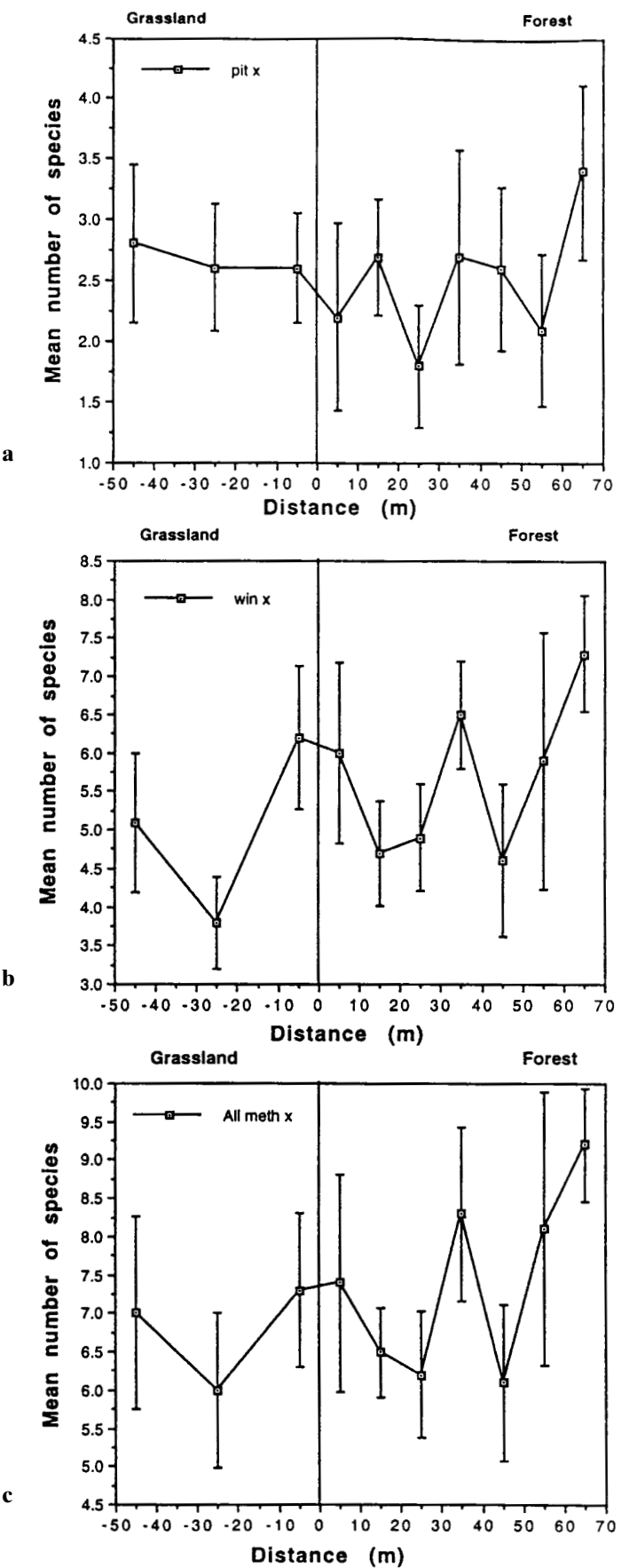

Figure 1. Mean (and standard error) number of ant species sampled by (a) pitfall traps, (b) by Winkler sacks and (c) both methods combined along the 10 transects extending from the field into the rain forest. The vertical line indicates the position of the fence around the forest reserve 


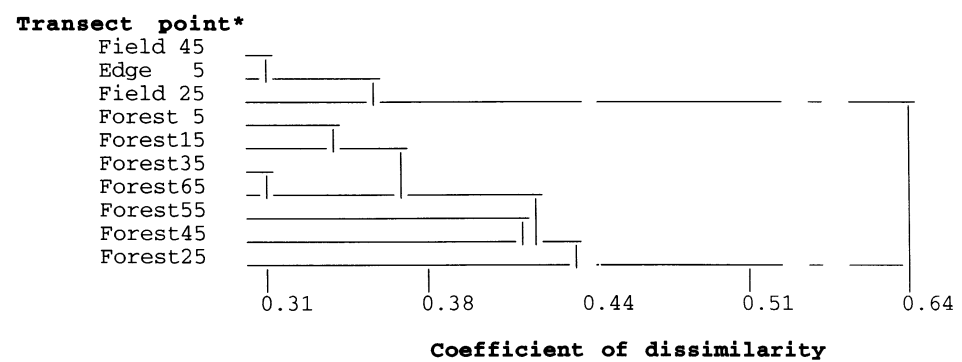

Figure 2. Transect points classified by UPGMA dendrogram according to similarities in their ant species composition

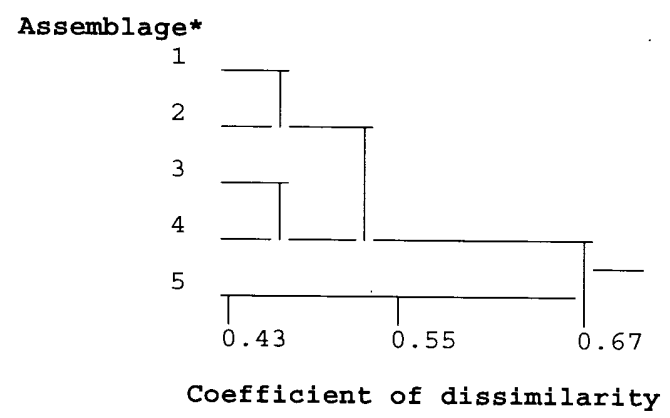

Figure 3. Ant species classified by UPGMA dendrogram according to their co-occurrences at the same transect point. The 0.44 level of dissimilarity was used to define the ant assemblages. * See Table 1 for list of ant species in each assemblage

gram of ant species when this was cut at the 0.44 coefficient of dissimilarity level (Fig. 3).

These analyses were used to re-order the data matrix in the form of a two-way table, which exposed the trends in ant species composition in the groupings of transect points described above (Table 1). The largest grouping contained species which were ubiquitous along the transects or which were ubiquitous except for points outside the forest. Group 2 comprized ants which showed a tendency to occur around the outer forest margin, while groups 3 and 4 contained ants which were generally found in deeper forest. The remaining group contained 12 species which were only found in the field or planted edge.

The ordination of transect points (not shown here) reiterated the trend shown in the transect point dendrogram, namely that the forest points form one cluster and the field and edge points form another cluster in terms of their ant species composition. The lengths of the connections on the associated minimum-spanning tree again support the view that the forest transect points are clustered at a considerable distance from the field plus planted edge points in terms of ant species composition.

We further investigated these trends by deriving a dendrogram for the 100 individual sampling points using the presence/absence of ant species at each point. In 
this analysis the association measure "two-step" (Belbin, 1980) was used to determine the quantitative relationships between each pair of species based on their distribution across sampling points. Secondly, the Czekanowski measure (Faith et al., 1987) was used to compare the sampling points according to similarities in ant species composition. The resulting dendrogram of sampling points produced no clear separation of field and forest points or even of field plus forest gap versus closed forest sites. It seems that the serendipitous variability in ant species captured at each site obscured any trend along the transects, rendering this analytical approach unprofitable in this instance. This noise may have been associated with the relatively low sampling intensity at each point.

\section{Discussion}

The results of this survey reveal an abrupt differentiation in forest and field ant community composition. Inspection of the ants which comprize the five assemblages (Table 1) helps throw some light on this trend.

The field and planted edge assemblage (5) contains a number of species which are common in open habitats. Ectatomma quadridens is one of the most characteristic species of cleared land, including urban areas, within Bahia. Camponotus crassus tends to occur under similar circumstances, while Pseudomyrmex sp. 1 is also common in open habitats.

The ubiquitously occurring assemblage (1) appears to contain two subsets of ants; those which occur in both field and forest and those which are found at all points along the forest part of the transects. The former subset contains Solenopsis saevissima and Wasmannia sp. 1, which nest in open habitats but which may be able to enter the forest by nesting in clearings where trees have fallen or died; a number of such areas occurred in the forest. In addition, the tramp species Monomorium floricola and Wasmannia auropunctata occur in this subset and are found in a wide range of disturbed habitats (Delabie, 1988). The inclusion of Pachycondyla harpax and Odontomachus haematodus is surprising as they require shade and/or dense vegetation (Smith et al., 1992); possibly their requirements are sufficiently provided for by the sparse array of trees and shrubs which locally persist in the field.

The forest-only subset of assemblage 1 contains a range of primary and secondary forest-associated species, including three of the litter-dwelling Octostruma spp. plus the wood- or cavity-nesting Odontomachus minutus and Camponotus cingulatus. Forest assemblages ( 3 and 4) contain a predominance of cryptic forest species including Rhopalothrix sp. 1, Hylomyrma sp. 1 and Apterostigma sp. 2.

Assemblage 2 consists of ant species which appear to favour the forest's periphery. Of note amongst the list are the tramp species Paratrechina longicornis and Pheidole megacephala which commonly invade disturbed areas and the soldier ant Labidus coecus, which is a major predator in more open areas (Fowler, 1979) where competition from other forest-associated Ecitoninae is less intense.

Despite the fact that differences between forest and field are clearly discernable, a surprising number of species are common to both habitats. A number of factors might have contributed to this phenomenon. Firstly, a number of clearings exist in the forest where trees have died or fallen, and some elements of the forest still per- 
Table 1. Two-way table of ant species by transect position. The grouping are those derived from the transect point dendrogram (Fig. 2) and the ant species dendrogram (Fig. 3)

\begin{tabular}{|c|c|c|c|c|c|c|c|c|c|c|c|}
\hline & & 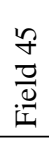 & 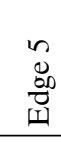 & $\frac{n}{2}$ & $\begin{array}{l}n \\
n \\
\overrightarrow{0} \\
0 \\
0 \\
I\end{array}$ & $\begin{array}{l}n \\
\tilde{w} \\
0 \\
0 \\
0 \\
1\end{array}$ & $\begin{array}{l}n \\
m \\
\overline{0} \\
0 \\
0 \\
0\end{array}$ & 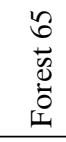 & $\begin{array}{l}n \\
n \\
5 \\
0 \\
0 \\
0 \\
\end{array}$ & 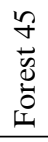 & 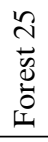 \\
\hline \multirow[t]{49}{*}{1} & Eciton burchelli & & 2 & & 1 & 1 & 1 & 1 & 2 & 1 & \\
\hline & Megalomyrmex goeldii & & & 1 & 2 & 1 & 1 & 1 & 1 & 1 & \\
\hline & Mycocepurus smithii & & 1 & & 3 & & 2 & 1 & 1 & 1 & \\
\hline & Octostruma rugifera & & & & 1 & 1 & 1 & 1 & 2 & 2 & 1 \\
\hline & Odontomachus minutus & & & & 1 & 2 & 1 & 1 & 2 & 1 & 1 \\
\hline & Strumigenys subedentata & & 1 & & 1 & 3 & 1 & 2 & & 1 & 1 \\
\hline & Octostruma balzani & & & 1 & 1 & 1 & 4 & 1 & 1 & 2 & 1 \\
\hline & Pheidole sp. 10 & & & & 1 & & & 2 & 2 & 1 & 1 \\
\hline & Brachymyrmex sp. 1 & & & & 3 & 2 & 2 & 2 & & & 2 \\
\hline & Octostruma petiolata & & & & 2 & & 2 & 4 & 1 & & 2 \\
\hline & Pheidole sp. 4 & & & & 1 & 2 & 2 & 3 & 2 & 2 & 3 \\
\hline & Solenopsis sp. 3 & & & & 2 & 5 & 2 & 1 & & 2 & 2 \\
\hline & Camponotus cingulatus & & & & & & 4 & 2 & 1 & 1 & 2 \\
\hline & Pheidole sp. 1 & & & & & 1 & & 1 & & 3 & 2 \\
\hline & Paratrechina sp. 1 & 2 & 1 & 2 & 1 & 1 & 3 & 2 & 3 & 1 & \\
\hline & Сурһотугтех sp. 1 & 4 & 4 & 2 & 2 & 2 & 1 & 2 & 1 & & \\
\hline & Strumigenys louisianae & 1 & 3 & 1 & 2 & 2 & 3 & 2 & 3 & 2 & 2 \\
\hline & Pachycondyla harpax & 2 & 3 & 1 & 2 & 3 & 4 & 1 & 2 & 4 & 1 \\
\hline & Solenopsis saevissima & 1 & 4 & 3 & 1 & 1 & 1 & 1 & & & \\
\hline & Solenopsis sp. 1 & 2 & 3 & 2 & 1 & 1 & 2 & 1 & & & 2 \\
\hline & Crematogaster sp. 1 & 1 & 1 & 1 & 2 & 1 & 1 & 3 & 2 & & 2 \\
\hline & Pheidole sp. 5 & 1 & & & 2 & 2 & 1 & 3 & 2 & & \\
\hline & Crematogaster sp. 2 & 3 & 1 & 2 & 1 & & & 1 & & 1 & 1 \\
\hline & Monomorium floricola & 3 & 1 & 1 & & 1 & 1 & & & 1 & \\
\hline & Wasmannia sp. 1 & 1 & 1 & 1 & 1 & & & & & 1 & \\
\hline & Paratrechina sp. 3 & 6 & 5 & 3 & 3 & 4 & 4 & 4 & 3 & 3 & 1 \\
\hline & Solenopsis sp. 2 & 6 & 5 & 7 & 4 & 5 & 5 & 4 & 2 & 3 & 4 \\
\hline & Odontomachus haematodus & 5 & 6 & 4 & 1 & 2 & 4 & 3 & 2 & 2 & \\
\hline & Pheidole sp. 2 & 1 & 2 & 1 & 3 & 5 & 4 & 6 & 1 & 3 & 4 \\
\hline & Solenopsis sp. 4 & 2 & 10 & 3 & 6 & 5 & 7 & 10 & 8 & 6 & 7 \\
\hline & Wasmannia auropunctata & $\overline{7}$ & 8 & 5 & 6 & 7 & 9 & 6 & 7 & 5 & 6 \\
\hline & Strumigenys denticulata & 6 & 5 & 6 & 4 & & 1 & & 2 & & 1 \\
\hline & Hуроропега sp. 2 & 5 & 3 & 1 & & & & & 2 & & 1 \\
\hline & Eciton vagans & & & & & & 1 & & & & \\
\hline & Typhlomyrmex sp. 1 & & & & & & 1 & & & & \\
\hline & Camponotus sexguttatus & & & 1 & & & 1 & & & & \\
\hline & Pheidole fimbriata & & 1 & 1 & & & 1 & 1 & & & \\
\hline & Leptogenys arcuata & & & 1 & & & 1 & 1 & & & \\
\hline & Pachycondyla apicalis & & & 1 & & & 1 & 2 & & & \\
\hline & Labidus praedator & 1 & & & & 1 & & 2 & & & \\
\hline & Strumigenys sp. 5 & 1 & & & & & & 1 & & & \\
\hline & Pheidole sp. 6 & & & & & 1 & 1 & 1 & 1 & & 1 \\
\hline & Anochetus bispinosus & & & & & & 1 & 1 & 1 & & \\
\hline & Rogeria sp. 1 & & & & & & & 1 & & & 1 \\
\hline & Camponotus abdominalis & & & & & & & 1 & & 1 & \\
\hline & Octostruma stenognatha & & & & & & & 1 & & 2 & \\
\hline & Camponotus novogranadensis & & & & & & & 1 & & & \\
\hline & Myrmicocrypta sp. 1 & & & & & & & 1 & & & \\
\hline & Hypoponera sp. 4 & & & & & & & 1 & & & \\
\hline
\end{tabular}


Table 1 (continued)

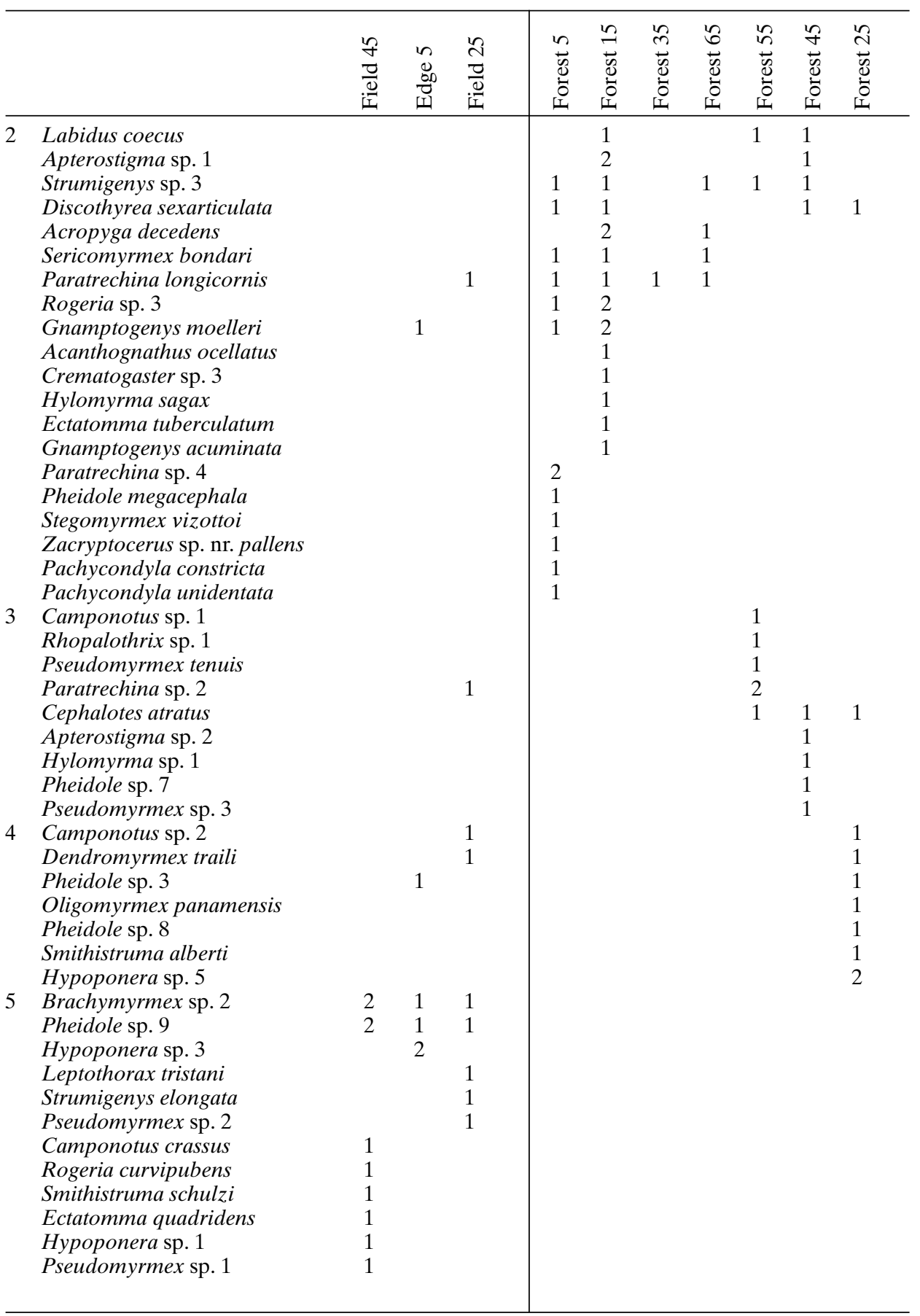


sist in the field. This may have blurred the distinction between forest and field ant communities. Secondly, up until around 1970 the forest reserve had been used for growing cocoa. Although the cocoa had been grown by the "cabruca" system, in which much of the original overstorey remained, this undoubtedly resulted in a modification of the ecosystem. Some parts of the reserve still show signs of this former land use, indicating that a degree of disturbance is still evident. Had the forest been in a more pristine state, the differentiation in ant fauna between the forest and the more drastically disturbed field might have been more evident.

Was the field section of the transects of sufficient length to detect the transition between field and forest ant faunas? Possibly not, as a whole range of characteristically forest species were captured at either $25 \mathrm{~m}$ or $45 \mathrm{~m}$ away from the forest. While many species were found at varying distances into the forest (Table 1) and the forest part of the transect appeared to detect changes in ant community composition at different distances from the edge, most of these forest "specialists" were infrequent, indicating that differences between transect distances were likely to be due to chance rather than reflecting any zonation in composition. This effect would explain why no trends related to position along transect were evident among the forest groups in Figure 2. There was evidence that species richness was higher $65 \mathrm{~m}$ into the forest than at any other point along the transect (Figs. 1a-c). Reasons why no edge effects are detectable in the ant community, even 5 to $15 \mathrm{~m}$ from the edge, are unknown, but no clear cut changes in shrub or canopy density or litter depth were evident in this region of the transects, despite visible differences in the composition of vegetation and a number of shrub species from the field invading the forest. Had the forest not been fenced it is likely that degradation of the forest might have intruded over a greater distance. It would be interesting to see whether the ant fauna is influenced to a greater extent than here in conditions such as this.

This investigation of a forest edge adjacent to a grassy field represents a worsecase scenario for this part of Brazil. One of the major land uses in eastern Bahia is the growing of cocoa. Cocoa is traditionally grown under forested shade trees and cocoa farms retain many structural elements of the original forest. Belshaw and Bolton (1993) have found that in Ghanaian cocoa, the litter ant fauna is virtually identical to that of the original rain forest. Thus the edge effect in forest adjacent to cocoa, such as on the other margins of this forest reserve, may also be low or nonexistent.

\section{Acknowledgements}

We wish to thank the following CEPLAC staff and students for assistance in the field and laboratory: José Raimundo Maia dos Santos, José Crispim Soares do Carmo, Antonio Carlos Moreira, Jackson S. Assis, Ivan Cardoso do Nascimento, Haroldo Santos, Paula Andréa Oliveira Soares, Cléa S. F. Mariano, Maria de Fátima S. dos Santos, Valéria Rodrigues Lavigne de Mello and Lívia Araújo Lessa. Dr. Alan Andersen and two anonymous referees kindly commented on an earlier draft of this paper. 


\section{References}

Alvim de, P., T. Rosário and M. Rosário, 1972. Cacau Ontem e Hoje. CEPLAC, Itabuna, Brazil. $83 \mathrm{pp}$.

Becker, P., J. S. Moure and F. J. A. Peralta, 1991. More about euglossine bees in Amazonian forest fragments. Biotropica 23:586-591.

Belbin, L., 1980. TWOSTEP: a program incorporating asymmetric comparisons that uses two steps to produce a dissimilarity matrix. CSIRO Division of Land Use Research Technical Memorandum 80/9. CSIRO, Canberra.

Belbin, L., 1991. SSH: Semi-strong Hybrid Scaling. J. Veg. Sci. 2:491-496.

Belbin, L., 1995. PATN Analysis Package. CSIRO Division of Wildlife and Ecology, Canberra. $220 \mathrm{pp}$.

Belshaw, R. and B. Bolton, 1993. The effect of forest disturbance on leaf litter ant fauna in Ghana. Biodiv. and Cons. 2:656-666.

Besuchet, C., D. H. Burckardt and I. Loble, 1987. The "Winkler/Moczarski" eclector as an efficient extractor for fungus and litter Coleoptera. Coleopt. Bull. 41:392-394.

Cãmara, C. de G., 1991. Plano de Ação para a Mata Attãntica. Fundação SOS Mata Atlãntica, São Paulo. 142 pp.

Camargo, J. L. C. and V. Kapos, 1995. Complex edge effects on soil moisture and microclimate in central Amazonian forest. J. Trop. Ecol. 11:205-221.

Delabie, J.H.C., 1988. Ocorrência de Wasmannia auropunctata (Roger, 1863) (Hymenoptera, Formicidae, Myrmicinae) em cacauais na Bahia, Brasil. Rev. Theobr. 18:29-37.

Daily, G. C. and P. R. Ehrlich, 1995. Preservation of biodiversity in small rainforest patches: rapid evaluations using butterfly trapping. Biodiv. and Cons. 4:35-55.

Faith, D.P., P. R. Minchin and L. Belbin, 1987. Compositional dissimilarity as a robust measure of ecological distance: A theoretical model and computer simulations. Vegetatio 69:57-68.

Fonseca da, G. A. B., 1985. The vanishing Brazilian Altanic forest. Biol. Cons. 34:17-34.

Fonseca de Souza, O.F. and V.K. Brown, 1995. Effects of habitat fragmentation on Amazonian termite communities. J. Trop. Ecol. 10:197-206.

Fowler, H.G., 1979. Notes on Labidus praedator (Fr. Smith) in Paraguay (Hymenoptera: Formicidae: Dorylinae: Ecitonini). J. Nat. Hist. 13:3-10.

Klein, B.C., 1989. Effects of forest fragmentation on dung and carrion beetle communities in Central Amazonia. Ecology 70:1715-1725.

Leston, D., 1978. A Neotropical ant mosaic. Ann. Ent. Soc. Amer. 71:649-653.

Lovejoy, T.E., R. O.J. Bierregaard, A. B. Rylands, J. R. Malcolm, C.E. Quintela, L.H. Harper, K. S. J. Brown, A. H. Powell, G. V.N. Powell, H. O. R. Schubart and M. B. Hays, 1986. Edge and other effects of isolation on Amazon forest fragments. In: Conservation Biology: The Science of Scarcity and Diversity (M. Soulé, Ed.), Sinauer Associates Inc., Sunderland, Massachusetts. pp. 257-285.

Malcolm, J. R., 1988. Small mammal abundances in isolated and non-isolated primary forest reserves near Manaus, Brazil. Acta Amazonica 18:67-83.

McKenzie, N. L., L. Belbin, G. J. Keighery and K. F. Kenneally, 1991. Kimberley rainforest communities: Patterns of species composition and Holocene biogeography. In: Kimbeley Rainforests. (N.L. McKenzie, R. B. Johnston and P. G. Kendrick, Eds.), Surrey Beatty and Sons, Chipping Norton. pp. 423-451.

Mills, L.S., 1995. Edge effects and isolation: red-backed voles in forest remnants. Cons. Biol. 9:395-403.

Mori, S. A., B. M. Boom, A. M. de Carvalho and T.S. dos Santos, 1983. Southern Bahian moist forests. Bot. Rev. 49:155-232.

Olson, D. M., 1991. A comparison of the efficacy of litter sifting and pitfall traps for sampling leaf-litter ants (Hymenoptera: Formicidae) in a tropical wet forest, Costa Rica. Biotropica $23: 166-172$.

Powell, A.H. and G. V.N. Powell, 1987. Population dynamics of male euglossine bees in Amazonian forest fragments. Biotropica 19:176-179.

Rylands, A. B. and A. Keuroghlian, 1988. Primate populations in continuous forest and forest fragments in central Amazonia. Acta Amazonica 18:291-307. 
Saunders, D. A., G. W. Arnold, A. A. Burbidge and A. J. M. Hopkins, Ed., 1987. Nature Conservation: The Role of Remnants of Native Vegetation. Surrey Beatty and Sons: Chipping Norton, NSW. 410 pp.

Saunders, D. A., R. J. Hobbs and C. R. Margules, 1991. Biological consequences of ecosystem fragmentation. Biol. Cons. $5: 18-32$.

Scougall, S. A., J.D. Majer and R. J. Hobbs, 1993. Edge effects in grazed and ungrazed Western Australian wheatbelt remnants in relation to ecosystem reconstruction. In: Nature Conservation 3: Reconstruction of Fragmented Ecosystems. (D. A. Saunders, R. J. Hobbs and P. R. Ehrlich, Eds.), Surrey Beatty and Sons, Chipping Norton, NSW. pp. 163-178.

Smith, M. R. B., J. H. C. Delabie, I. M. Cazorla, A. M. V. da Encarnacao, A. B. Casimiro, I. C. Nascimento, A. L. B. Souza and M. Furst, 1992. Uso de formigas como bioindicadores entre vegetação atividades agricolas e comunidades de formicidae. Resumos do XIX Congresso Brasileiro de Zoologia, Sociedade Brasileira de Zoologia, Belem, PA 74-75.

Sneath, P.H. A. and R. R. Sokal, 1973. Numerical taxonomy. The principals and practice of numerical classification. W. H. Freeman, San Francisco. 359 pp.

Turner, I. M., 1996. Special loss in fragments of tropical rain forest: a review of the evidence. J. App. Ecol. 33:200-209.

Vasconcelos, H. L. and J. M. Cherrett, 1995. Changes in leaf-cutting ant populations (Formicidae: Attini) after clearing of mature forest in Brazilian Amazonia. Stud. Neotrop. Fauna and Env. 30:107-113.

Vasconcelos, H. L., J.H. C. Delabie and A. B. Casimiro, 1997. Ground ant communities from central Amazonia forest fragments. In: Ecology and Conservation of Fragmented Forests. (R. O. J. Bierregaard, C. Gascon and A. A. dos Santos, Eds.) (in press).

Wilcox, B. A. and D. D. Murphy, 1985. Conservation strategy: the effect of fragmentation on extinction. Amer. Nat. 125:879-887.

Received 23 October 1996;

revised 2 January 1997;

accepted 26 March 1997. 